\title{
二段給電式ミグ溶接プロセスと従来型ミグ溶接プロセス におけるビードのぬれ性の比較検討
}

\section{Comparison of Wettability of Beads in MIG Welding Process with Duplex Current Feeding and Conventional MIG Welding Process}

\author{
瀬渡＼cjkstart賢*・青木篤人*・田代真 一***田中 学** \\ Masaru SETO, Atsuhito AOKI, Shinichi TASHIRO and Manabu TANAKA
}

(Received November 13. 2016)

\begin{abstract}
In order to perform stable pure argon MIG welding, duplex current feeding MIG welding has been developed. In the previous experimental study, higher droplet temperature and deeper weld penetration were obtained in the duplex current feeding MIG welding compared with those of the conventional MIG welding. However, the similar effects are considered to be realized also by the conventional MIG welding with short wire extension through increase in welding current. In this paper, basic characteristics of the duplex current feeding MIG welding were compared with those of the conventional MIG welding with the short wire extension. Consequently, it was found that the duplex current feeding MIG welding achieved the deeper weld penetration without an undercut unlike in the case of the conventional MIG welding with the short wire extension.
\end{abstract}

Key Words: MIG welding,Pure Argon Shielding Gas, Duplex Current Feeding, Wire Extension, Droplet Temperature, Two-Color Pyrometry

\section{1. 緒 言}

極低温用鋼構造物や橋梁等の高強度鋼構造物の安全性を 確保するためには、溶接部の強度ならびに靯性の両立が必 須であるが、低温用鋼ならびに高強度鋼の溶接施工中に溶 融金属に酸素、窒素等が混入すると鞎性が低下する。この ため、この種の鋼種では不活性雲囲気下で安定した施工が 可能なティグ溶接が主に使われている。このティグ溶接は 䩲性も含めて高品質な溶接継手が得られるものの溶接施工 能率が悪いといった問題がある。一方で、高能率なミグ溶 接は純アルゴンシールド雲囲気では溶接が不安定になるた め、一般的にはシールドガスとしてアルゴンガスに酸素や 二酸化炭素を添加されたものが使用されており、これらの ガスの混入により、鞁性が低下する傾向にある ${ }^{1)}$

そこで高品質、高能率を両立した溶接を行うために純不 活性䨌囲気下でのミグ溶接（以下、クリーンミグ溶接と記 す）が必要とされている。このクリーンミグ溶接では不規 則に陰極点が移動することによりアークが不安定になり、 溶接ビードの蛇行が発生すること ${ }^{2)}$ や溶接金属の表面張力 が高いこと ${ }^{3), 4}$ に起因する凸型ビード形成が問題となってい る。クリーンミグ溶接によるアークの不安定や凸型ビード
は、多層溶接の場合、パス間の融合不良といった溶接欠陥 を発生し、それを防止するためにパス間グラインダーによ る溶接ビードの修正を余儀なくされ、工数の増加の要因と なる。

アークの不安定に関しては、上園らが、不規則な陰極点 挙動により発生する高い電圧を異常值として判別し、異 常電圧が発生する前のアーク特性上の電圧值を代入して 補うデジタルフィルタリング処理を行なうことによって、 フィードバック電圧に含まれる外乱の影響を大きく改善す ることを可能とした ${ }^{5)}$ 。

中村らはワイヤ溶融先端液柱がアーク中で極めて長く伸 び、かつ大きく不規則に振動している現象が不安定ビード の大きな要因の一つであると判断し、細長く伸びた液柱を 短くし変動挙動を抑止するために、中心部の材質の融点が 周辺部よりも低くなるように径方向のワイヤ組成を設計し た同軸複層ワイヤを開発し、ミグアークの安定化に成功し ている ${ }^{2)}$ 。

銭谷らは溶接安定化に必要最低限の酸素量を供給するた め、シールドガスには純アルゴンを用い溶融金属柱近傍に ワイヤとコンタクトチップの隙間から局部的に微量酸素を 軸流添加するプロセスを開発し、シールドガス中の平均酸

*川崎重工業株式会社技術開発本部 システム技術開発センター（テ673-8666 兵庫県明石市川崎町1-1）

System Technology Development Center, Corporate technology Division, Kawasaki Heavy Industries,Ltd.

(1-1 Kawasaki-cho, Akashi, Hyogo, 673-8666 Japan)

* * 大阪大学 接合科学研究所 ( $\bar{\top} 567-0047$ 大阪府茨木市美穂ヶ丘11-1)

Joining and welding research Institute, Osaka University (11-1 Mihogaoka, Ibaraki, Osaka,567-0047 Japan) 
素濃度を低く抑えつつ溶接の安定性を向上できることを確 認した ${ }^{6}$ 。

田中らはクリーンミグ溶接における不安定現象の要因と して不規則な陰極点挙動とワイヤ端液柱の摇動の二点に着 目し、両者の課題を解決する溶接プロセスとして電離シー ルドガス流を活用するプラズマミグ溶接プロセスを提案し た ${ }^{7)}$ 。プラズマミグ溶接プロセスはアークの安定化に至っ たものの、依然ビードのぬれ性が悪く、溶込みが浅いとい う点に問題があった。

これらの研究では、アークの安定性は大きく向上したも のの、もうひとつの問題点である凸型ビード形成に関して は未解決であった。従来のクリーンミグ溶接において十分 なぬれ性が得られず凸ビードとなる原因として、溶融金属 の温度が低く、表面張力が高くなることが挙げられ、それ を改善するためには溶融金属の温度上昇が必要である。し かしながら、従来型ミグ溶接ではワイヤに流れる溶接電流 とワイヤ溶融量の一意的な関係を切り離せないために、溶 滴の温度すなわち溶融金属の温度を十分に上昇させられな いという課題がある。

そこで本研究では 2 台の溶接電源を用い、1 台は通常の ミグ溶接用として給電し、もう 1 台を溶接ワイヤ先端近く に給電することで、溶接電流とワイヤ送給量の一意的な関 係を切り離し、それらの独立制御を可能とする、二段給電 式ミグ溶接プロセスを開発している。

前報では本プロセスの実験装置を試作し、いくつかの条 件下で従来型ミグ溶接と二段給電式ミグ溶接を比較検討し た ${ }^{8)}$ 。Fig.1に二段給電式ミグ溶接の装置構成を示す。上 述のようにワイヤへの給電点を二つ設けており、給電チッ プ同士は接触しないようセラミックによって絶縁されてい る。トーチは二重構造になっておりセンターガスおよび シールドガスの両方に純アルゴンガスを流している。なお、 第一給電チップ下端から第二給電チップ下端までの距離は $12 \mathrm{~mm}$ となっている。二段給電式ミグ溶接では、従来のミ グ溶接における溶接電源に相当する第一電源は定電圧特性

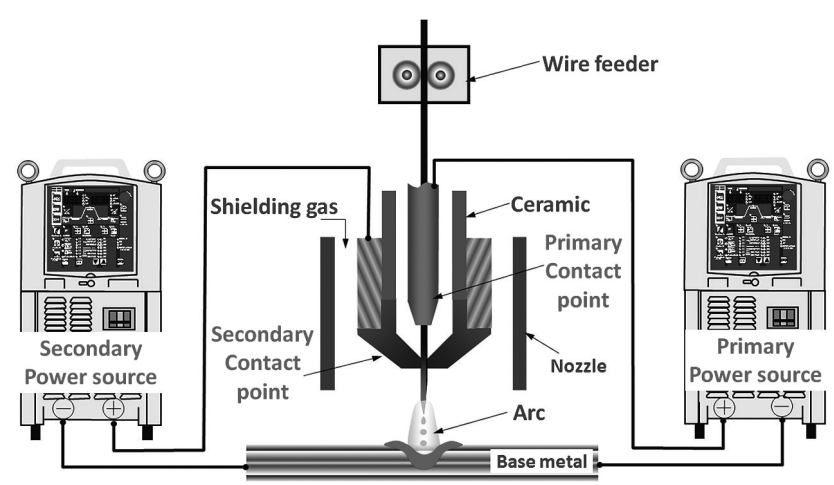

Fig.1 Schematic diagram of MIG welding process with duplex current feeding.
の直流パルス電流で第一給電点に、本研究で提案する第二 電源は定電流特性で第二給電点に接続されている。

二段給電式ミグ溶接プロセスの効果を検討した結果、第 二給電点に電流を通電することにより溶滴温度が上昇し、 従来型ミグ溶接では解決しがたい凸型ビード形成や溶込み 不足を改善できることを実験的に確認した。また、二段給 電式ミグ溶接における第一電流と第二電流を重ね合わせた 電流を従来型ミグ溶接に流したところ、ワイヤ送給量が増 加する結果、二段給電式ミグ溶接ほどのぬれ性が得られな いことが前報で ${ }^{8)}$ 確認された。

一方で、ワイヤ送給量を変えずに電流を増やすための手 段として、ワイヤ突出し長さを詰める手法が一般に用いら れている。これは、突出し長さが短くなることによりワイ ヤでの抵抗発熱が少なくなるため、同じワイヤ溶融速度 を保つためにはより多くの電流が必要となるためである。 本稿では従来型ミグ溶接においてワイヤ突出し長さを短 くし溶接電流を増やすことにより、二段給電式ミグ溶接と 同等の効果が得られるかについて検討した結果について 報告する。

\section{2. 実験方法}

本研究では、従来型ミグ溶接トーチ及び定電圧特性電源 を用いて、ワイヤ突出し長さを短くして溶接電流の増加を はかった条件下で溶接を行い、二段給電式ミグ溶接の基礎 特性との比較検討を行う。前報 ${ }^{8)}$ における実験条件に揃える ため、ワイヤ送給速度を $8 \mathrm{~m} / \mathrm{min}$ 、溶接速度を $50 \mathrm{~cm} / \mathrm{min}$ 、 全ガス流量を $30 \mathrm{~L} / \mathrm{min}$ とした。母材には板厚 $9 \mathrm{~mm}$ の軟鋼 板、溶接ワイヤには、J1S Z3312 YGW15 相当の $\phi 1.2 \mathrm{~mm}$ ソリッドワイヤを用いた。シールドガスは純アルゴンを流 し、その流量は $30 \mathrm{~L} / \mathrm{min}$ とした。コンタクトチップー母 材間距離（Contact Tip to Work Distance 以下、CTWD と記 す）はワイヤ突出し長さの影響を検討するため、15 mm ま たは $20 \mathrm{~mm}$ とし、ビードオンプレート溶接を実施した。前 報で報告した二段給電式ミグ溶接及び従来型ミグ溶接の結 果は、ともにCTWD $30 \mathrm{~mm}$ のものであった。本報ではこ れら 2 点の結果も引用し、合計 4 条件（従来型ミグ溶接の CTWD $15 \mathrm{~mm} 、 20 \mathrm{~mm} 、 30 \mathrm{~mm}$ ならびに二段給電式ミグ溶 接の CTWD $30 \mathrm{~mm}$ ）について比較する。

また、アーク長をCTWD $30 \mathrm{~mm}$ の場合と同じおよそ4 $\mathrm{mm}$ にし、比較しやすくするため適宜溶接電圧の調整を行っ た。溶接中、アークの様子を高速度ビデオカメラで撮影す るとともに、データロガーを用いてその際の両電源の電流・ 電圧波形についても併せて計測した。

溶滴温度は溶込み深さやビード形状に大きく影響するも のと考えられる。このため、分光器付き高速度ビデオカメ ラを用いて、二色放射測温法による溶滴表面温度の計測を 行った。対物レンズから入射した高温物体からの画像（放 射光）をビームスプリッターによって二つに分割し、それ 


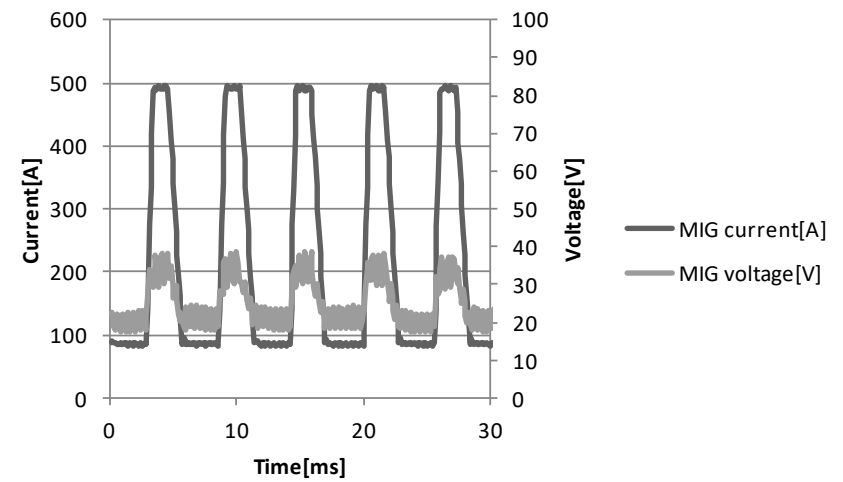

(a) CTWD $20 \mathrm{~mm}$

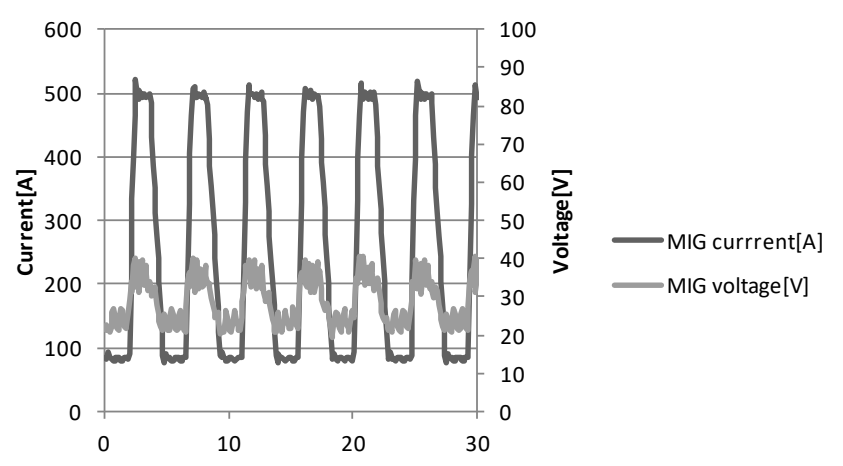

(b) CTWD $15 \mathrm{~mm}$

Fig.2 Waveform of welding current and voltage of conventional MIG welding.

ぞれが異なる 2 つ波長の干渉フィルター（中心波長 950 $\mathrm{nm}$ と $980 \mathrm{~nm}$ ) を通過して、高速度デジタルビデオカメラ の素子表面で結像して画像として記録される。そして、各 画素の輝度比データに、標準ランプによる較正実験から得 られた計算式を与えることにより、溶滴表面温度分布を

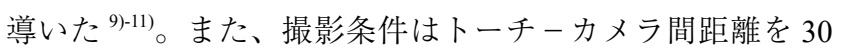
$\mathrm{cm}$ 、撮影速度 $500 \mathrm{fps}$ 、シャッター速度 $1 / 500 \mathrm{sec}$ とした。

\section{3. 結果及び考察}

\section{1 電流・電圧波形の観測}

Fig.2(a)にCTWD $20 \mathrm{~mm}$ の場合の従来型ミグ溶接におけ る電流・電圧波形を、Fig.2(b)に同じくCTWD $15 \mathrm{~mm}$ の場 合の電流・電圧波形を示す。CTWD を短くした場合、すな わちワイヤ突出し長さを短くした場合、ミグ電流のベース 電流、ピーク電流、ピーク期間は一定であるので、ベース 期間が短くなり、パルス周波数が高くなることによって平 均電流值が増加していることが分かる。この時のミグ電流 の平均值は CTWD $20 \mathrm{~mm}$ の場合が $226 \mathrm{~A} 、 \mathrm{CTWD} 15 \mathrm{~mm}$ の 場合が 262 A となった。二段給電式ミグ溶接の第一電流 (156 A) と第二電流 (50 A) の合計值が 206 A だったので、CTWD $20 \mathrm{~mm}$ の場合には二段給電式ミグ溶接より $20 \mathrm{~A}$ 多くの電流 が流れており、CTWD $15 \mathrm{~mm}$ の場合には二段給電式ミグ溶

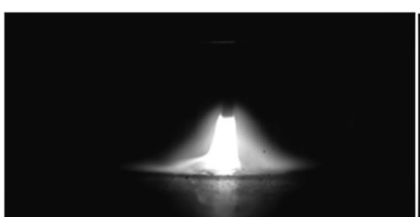

(a) CTWD $20 \mathrm{~mm}$

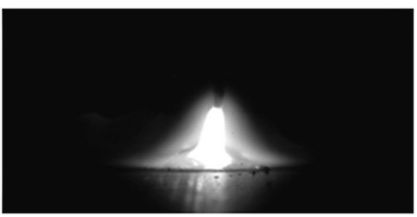

(b) CTWD $15 \mathrm{~mm}$
Fig.3 Arc phenomena of conventional MIG welding.

接よりおよそ $55 \mathrm{~A}$ 多くの電流が流れていることになる。

\section{2 高速度カメラによるアーク外観および溶滴移行観察}

Fig.3(a)にCTWD $20 \mathrm{~mm}$ の場合の従来型ミグ溶接におけ るアーク外観を、Fig.3(b)にCTWD $15 \mathrm{~mm}$ の場合の従来 型ミグ溶接におけるアーク外観を示す。なお、この時の撮 影方向は溶接進行方向正面からとし、撮影条件はトーチー カメラ間距離 $50 \mathrm{~cm}$ 、撮影速度 $4000 \mathrm{fps}$ 、シャッター速度 1/22000 sec として撮影を行った。CTWDを短くするに伴い ミグ電流のパルス周波数が増加するため、それに伴って溶 滴移行周波数も増加することが分かった。どちらも 1 パル ス 1 溶滴の移行となっている瞬間が多かった。二段給電式 ミグ溶接と比較すると、溶滴移行周波数が CTWD $20 \mathrm{~mm}$ の 場合、 $15 \mathrm{~mm}$ の場合の順に増加していくため溶滴の大きさ は、二段給電式ミグ溶接 > CTWD $20 \mathrm{~mm}$ の場合 $>$ CTWD $15 \mathrm{~mm}$ の場合となった。

\section{3 ビード外観およびマクロ断面の観察}

Fig.4(a) 及び (b) に、CTWD $20 \mathrm{~mm}$ 及びCTWD $15 \mathrm{~mm} の$ 場合の従来型ミグ溶接におけるビード外観およびそのマク ロ断面を示す。また、比較対象として Fig.4(c)に CTWD 30 $\mathrm{mm}$ の場合の従来型ミグ溶接におけるビード外観およびそ のマクロ断面を示す。Fig.5に二段給電式ミグ溶接のビー ド外観及びマクロ断面を示す。

Fig.4 を見ると CTWD が短くなるにつれてビード止端部 は不揃いで所々掘り下げられた部分が生じるが、溶込みが 深くなりぬれ性は改善される傾向にあることが分かる。こ れはミグ電流の増加に伴うものであるが、Fig.4(a) と Fig.5 を見比べると従来型ミグ溶接において CTWDを $20 \mathrm{~mm}$ と した場合には二段給電式ミグ溶接と同等以上の電流が流れ ているにも関わらず二段給電式ミグ溶接ほどのぬれ性は得 られていないことが分かる。また Fig.4(b) と Fig.5を見比 ベると CTWDを $15 \mathrm{~mm}$ とした場合には二段給電式ミグ溶 接にかなり近いぬれ性が得られるものの、ビードのぬれ性 が均一でなく所々深いアンダカットを生じることが分かっ た。これはワイヤ送給量に対し、平均電流が上昇し過ぎる ためにアークによって深く掘り下げられた溶融地に溶接金 属が十分に満たされないまま溶接が進行していくためと考 えられる。したがって突出し長さを短くすることによって 二段給電式ミグ溶接のような効果を得ようとすると、二段 


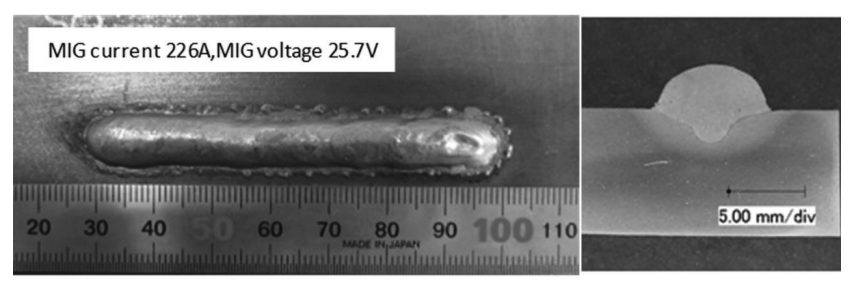

(a) CTWD $20 \mathrm{~mm}$

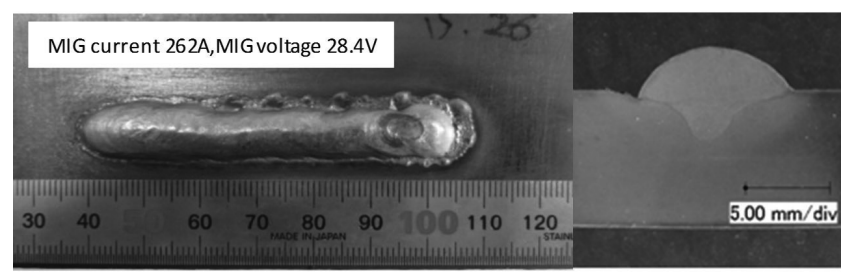

(b) CTWD $15 \mathrm{~mm}$

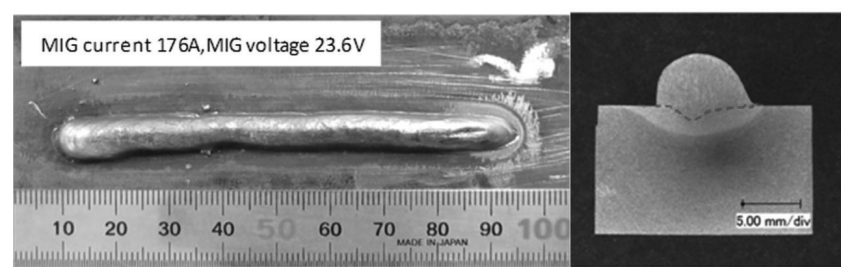

(c) CTWD $30 \mathrm{~mm}$

Fig.4 Bead appearance and cross section of conventional MIG welding.

給電式ミグ溶接と同程度の電流值では十分なぬれ性が得ら れず、同じほどのぬれ性を得るためにはより多くの電流值 を必要とし、その結果アンダカットのような溶接欠陥を招 く原因となり得るといえる。

また、従来型ミグ溶接において突出し長さによって電流 值を調整するには適正電流範囲が狭く難しいのに対し、二 段給電式ミグ溶接ではワイヤ送給量と溶接電流をある程度 独立して制御できるため、第二電流を調整することにより 突出し長さ一定のままでビード形成を改善できる。さらに 開先内の溶接等、トーチの近付ける限界のある場合を想定 すると CTWDを縮めるのにも限界があり、突出し長さの変 更が不要であることは大きな利点であるといえる。

\section{4 二色放射測温法による溶滴の表面温度測定}

アーク消弧直後の波長 $980 \mathrm{~nm}$ と $950 \mathrm{~nm}$ における CTWD $20 \mathrm{~mm}$ の場合の従来型ミグ溶接の分光画像を Fig.6(a)に、 同じくCTWD $15 \mathrm{~mm}$ の場合の従来型ミグ溶接の分光画像 をFig.6(b) に示す。なお、撮影方向は溶接進行方向正面か らとし、撮影条件はトーチ - カメラ間距離 $30 \mathrm{~cm}$ 、撮影速 度 $500 \mathrm{fps} 、 シ ャ ッ タ ー$ 速度 $1 / 500 \mathrm{sec}$ として撮影を行った。

この時の溶滴部分を切り出し、二つの異なる波長の輝度 比から溶滴の表面温度分布を求めた。CTWD $20 \mathrm{~mm}$ の場合 の溶滴の表面温度分布を Fig.7(a)に、CTWD $15 \mathrm{~mm}$ の表面 温度分布を Fig.7(b) に示す。比較詨象として CTWD $30 \mathrm{~mm}$ の場合の溶滴の表面温度分布を Fig.7(c) に、二段給電式ミ

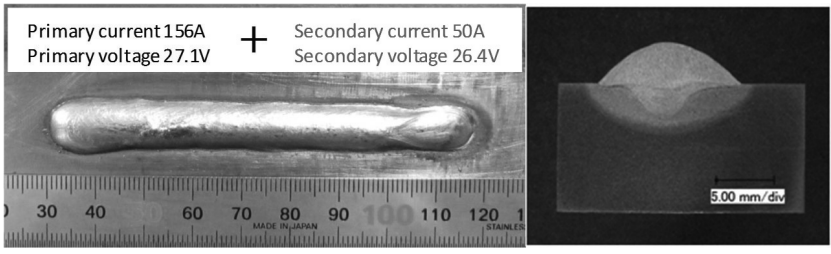

Fig.5 Bead appearance and cross section of MIG welding with duplex current feeding.

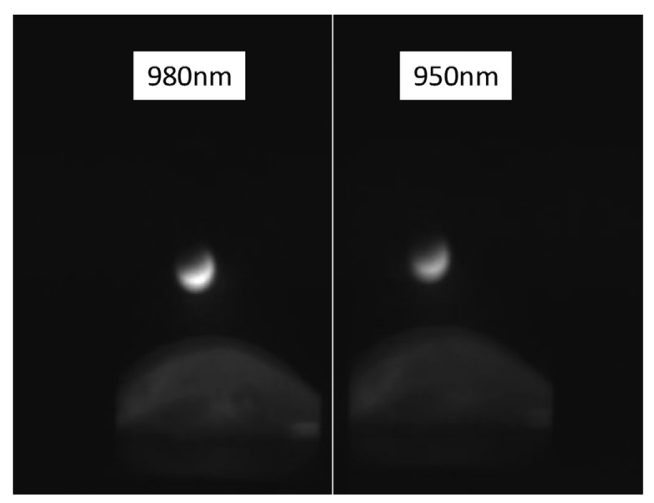

(a) CTWD $20 \mathrm{~mm}$

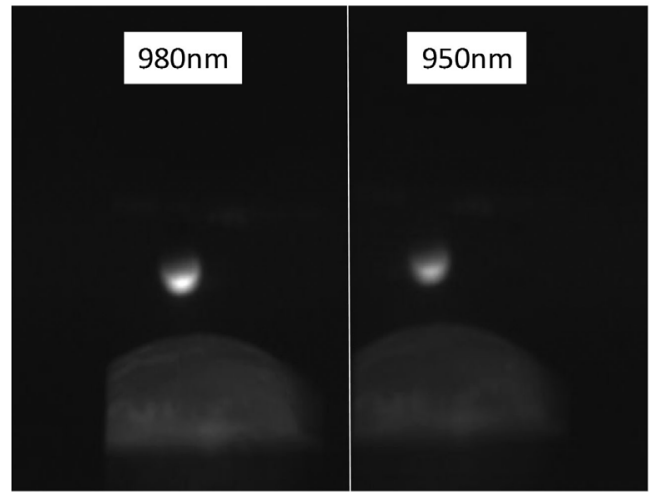

(b) CTWD $15 \mathrm{~mm}$

Fig.6 Spectroscopic image of $950 \mathrm{~nm}$ and $980 \mathrm{~nm}$ wavelength of conventional MIG welding.

グ溶接の場合の溶滴の表面温度分布を Fig.7(d) に示す。表 面温度はアーク消弧直後の分光画像から算出されており、 主にアークルートの形成されていた溶滴下部において表面 温度が高くなっていることがわかった。

この時の各々の溶滴の平均表面温度は CTWD $20 \mathrm{~mm}$ の 場合が $2020 \mathrm{~K} 、 \mathrm{CTWD} 15 \mathrm{~mm}$ の場合が $2110 \mathrm{~K}$ であった。 CTWD $30 \mathrm{~mm}$ の場合が $1870 \mathrm{~K}$ であったことと比較すると、 CTWD を短くし電流值が上昇するにつれて溶滴の温度が上 昇していくことが分かる。CTWDを短くすることでぬれ性 が向上するのはこの理由にあると考えられる。しかしなが ら二段給電式ミグ溶接の場合が $2160 \mathrm{~K}$ であったことと比較 すると従来型ミグ溶接では二段給電式ミグ溶接よりも多く 


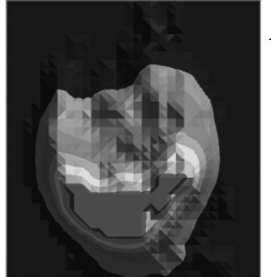

(a) CTWD $20 \mathrm{~mm}$

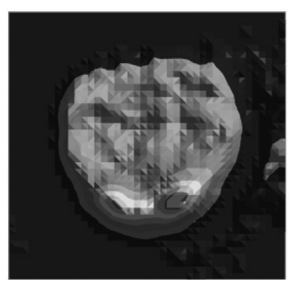

(c) CTWD $30 \mathrm{~mm}$

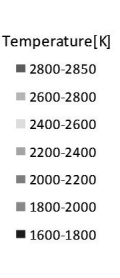

Temperature[K]
$=2800-2850$
$=2600-2800$
$=2400-2600$
$=2200-2400$
$=2000-2200$
$=1800-2000$
$=1600-1800$

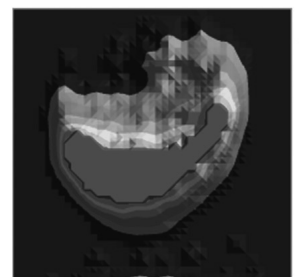

(b) CTWD $15 \mathrm{~mm}$

(d) MIG welding with duplex current feeding.

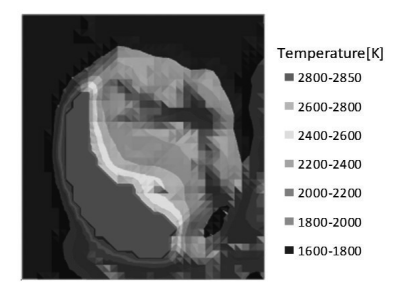

Fig.7 Surface temperature distribution on droplets of conventional MIG welding and MIG weldingwith dual current feeding.

の電流值が流れている場合でも二段給電式ミグ溶接と同等 の温度、もしくはそれ以下となることが分かった。したがっ て、二段給電式ミグ溶接では従来型ミグ溶接と比較して合 計で同じ電流を流した場合、より効率的に溶滴温度の上昇 が可能となることがわかった。

\section{4. 結 言}

本稿では、従来型ミグ溶接においてワイヤ突出し長さを 短くし溶接電流を増やすことにより、二段給電式ミグ溶接 と同等の効果が得られるかについて検討した。主要な結論 を以下に記す。

1) 従来型ミグ溶接において、CTWDを $15 \mathrm{~mm}$ まで短くす ると、電流值は $262 \mathrm{~A}$ まで増加し、二段給電式ミグ溶接 (CTWD $30 \mathrm{~mm})$ の全電流值である $206 \mathrm{~A}$ を大きく上回っ た。

2) 従来型ミグ溶接において、CTWDを短くするほど、ぬ れは性改善され溶込み深さは増加するが、電流值の増加 によりアンダカットを生じる結果となった。一方で、二
段給電式ミグ溶接では同程度の好性及び溶込み深さで あってもアンダカットは生じなかった。

3) 従来型ミグ溶接では、二段給電式ミグ溶接よりも多くの 電流值が流れている場合でも二段給電式ミグ溶接と同 等、もしくはそれ以下の溶滴温度にしかならないことが 判明した。

\section{参考文献}

1) S. Terashima and K.K.D.H.Bhadeshia: "Change in toughness at low oxygen concentrations in steel weld metals", Science and Technology of Welding and Joining, 11-5 (2006).

2) T. Nakamura and K. Hiraoka : "GMA Welding of $9 \% \mathrm{Ni}$ steel in the pure Argon shielding gas using coaxial multi-layer solid wire", Quarterly J. Japan Welding Soc., 30-3 (2012) 254-261.

3) S.A.David, T.Debroy and J.M.Vitek: "Phenomenological Modeling of Fusion Welding Process" MRS Bulletin, 10-1 (1994) 29-35.

4) 荻野和巳、城野清、細井千秋: “溶融 Fe-O-S 合金の表面張力”、 鉄と鋼、69 (1983) 48.

5) T.Uezono and H.Tong : “Applicatuion to MIG Welding Using Welding Power Source Equipped with Digital Filtering Process” J. J apan Welding Soc., 76-4 (2007) 43-46.

6) S. Zenitani, T. Nakamura, K. Hiraoka and K. Shinozaki: "Ar-MIG arc behavior in local addition of small amount of Oxygen into shielding gas", Quarterly J. Japan Welding Soc., 25-1 (2007) 187 195.

7) M. Tanaka, T. Tamaki, S. Tashiro, K. Nakata, T. Ohnawa and T. Ueyama : "Characteristic of ionized gas metal arc processing", Surface \& Technology, 202 (2008) 5251-5254.

8) M. Seto, A. Aoki, M. Tanaka, S. Tashiro and T. Era: "Study on new welding process with duplex current feeding”, Quarterly J. Japan Welding Soc., 34 (2016) 150-157.

9) K. Yamazaki, E. Yamamoto, K. Suzuki, F. Koshiishi, K. Waki, S. Tashiro, M.Tanaka and K. Nakata: "The Measurement of Metal Droplet Temperature in GMA Welding by Infrared Two-Color Pyrometry”, Quarterly J. Japan Welding Soc., 26-3 (2008) 214-219.

10) K. Yamazaki, E. Yamamoto, K. Suzuki, F. Koshiishi, K.Waki, S. Tashiro, M. Tanaka and K. Nakata : "The Measurement of Metal Droplet Temperature in GMA Welding by Infrared Two-Color Pyrometry", Quarterly J. Japan Welding Soc., 26-3 (2008) 214-219.

11) ランカスター：“溶接アークの物理”、溶接学会、溶接アーク 物理委員会 (1990). 